\title{
Benzothiazole-Based Bis-azo Cationic Fluorescent Dyes with Extended Conjugated Systems: Synthesis and Properties
}

\author{
Frahnaz Nourmohammadian, a,b,", Mohammad Yousef Alikhanic, Mahnaz Davoudzadeh \\ Gholami $^{\mathrm{a}}$ and Ali Ashtiani Abdi ${ }^{\mathrm{a}}$ \\ ${ }^{a}$ Center of Excellence for Color Science and Technology, Tehran, Iran \\ ${ }^{b}$ Department of Organic Colorants, Institute for Color Science and Technology, P.O. Box 654-16765, Tehran, \\ Iran \\ ${ }^{c}$ Department of Microbiology, Faculty of Medicine, Hamadan University of Medical Sciences, Hamadan, Iran
}

\begin{abstract}
Sixteen novel 2-aminobenzothiazole based dichromophoric cationic azo dyes were synthesized and their photophysical properties studied. The colors of the synthesized azo dyes were violet to blue with high molecular extinction coefficient ranged between $2.6-4.7 \times 10^{4}\left(\mathrm{M}^{-1} . \mathrm{cm}^{-1}\right)$. All of the dyes showed unique fluorescence emission at a broad range of 409-494 $\mathrm{nm}$. The absorption and emission spectral changes of selected dyes were also analyzed in solvents with different polarity. Furthermore, the antibacterial activities of the dyes were evaluated against gram positive and negative bacteria including S. aureus, S. epidermidis, E. coli, and $P$. aeruginosa and different concentrations of dyes showed an anti-gram positive bacterial activity.
\end{abstract}

Keywords: Benzothiazole, Azo Dyes, Fluorescence, Cationic dye, Antibacterial, Solvatochromism.

\section{INTRODUCTION}

2-aminobenzothiazole based diazonium dyes have found successful commercial utilization in production of cationic dyes [1-11]. In line with interest on benzothiazole cationic dyes for textiles dyeing [12], a diverse range of non-textile applications such as liquid crystal technology, reprography, nonlinear optics, and corrosion inhibitors have also been developed [13-24]. Recently, their biological activities such as antibacterial, antitumor, and antiviral activities have been reported as well [25-35].

Based on recently reported synthesis and application of dicationic dyes as bifunctional molecules $[5,22,32,36]$, and in keeping with our former investigations on novel bifunctional hemicyanine dyes [37-39], here we report synthesis of 2aminobenzothiazoles-based dichromophoric cationic azo. In addition, several properties of the synthesized dyes such as electronic absorption and emission properties were studied, and their solvatochromic behavior were analyzed using Lippert-Mataga correlation and Reichardt-Dimroth's $E_{T}(N)$ equation $[40,41]$. Antibacterial activities of the synthesized dyes were also evaluated against gram positive bacteria including Staphylococcus aureus, and Staphylococcus epidermidis, and gram negative bacteria as Escherichia coli and Pseudomonas aeruginosa.

*Address correspondence to this author at the Department of Organic Colorants, Institute for Color Science and Technology, P.O. Box 654-16765, Tehran, Iran; Tel: +98(21)22958314; Fax: +98(21)22947537;

E-mail: nour@icrc.ac.ir

\section{RESULTS AND DISCUSSION}

Glyoxal 1a or Terephthalaldehyde $\mathbf{1 b}$ was reacted with two equimolars of aniline to lead the corresponding Schiff base (or azomethine) $\mathbf{2} \mathbf{a}-\mathbf{b}$ in high yields (95 and 98\%) (Scheme 1). The symmetrical products $4 \mathbf{a}-\mathbf{h}$ were attained from the coupling of Schiff base $2 \mathbf{a}-\mathbf{b}$ with two equivalents of identical 6substituted-2-azobenxothiazole $3 \mathbf{a}-\mathbf{d}$, and asymmetrical products 4i-p were obtained using two equivalents of different 6-substituted-2-azobenxothiazole 3a-d (Scheme 1). The structures of compounds 4a-p were deduced from their mass spectroscopy and their IR, ${ }^{1} \mathrm{H}-\mathrm{NMR}$, and ${ }^{13} \mathrm{C}$-NMR spectroscopic and $\mathrm{CHN}$ analysis data and were in accordance with our previous report [38, 39].

Subsequently, novel cationic dyes (5a-p) were synthesized by quaternizaions of benzothiazole's amine groups of 4a-p in very good yields (78-88\%). Mass spectroscopy, IR, ${ }^{1} \mathrm{H}-\mathrm{NMR}$ spectroscopic and $\mathrm{CHN}$ analysis results confirmed the structures of the products 5a-p that are showed in Scheme $\mathbf{1 .}$

\section{Photophysical Properties}

The photophysical properties of the synthesized cationic dyes 5a-p were studied. The absorption spectral data are summarized in Table 1, and fluorescence characteristics of the selected dyes are presented in Table 2 . The fluorescence quantum yields were calculated using integrated fluorescence peak area versus fraction of light absorbed at the excitation 


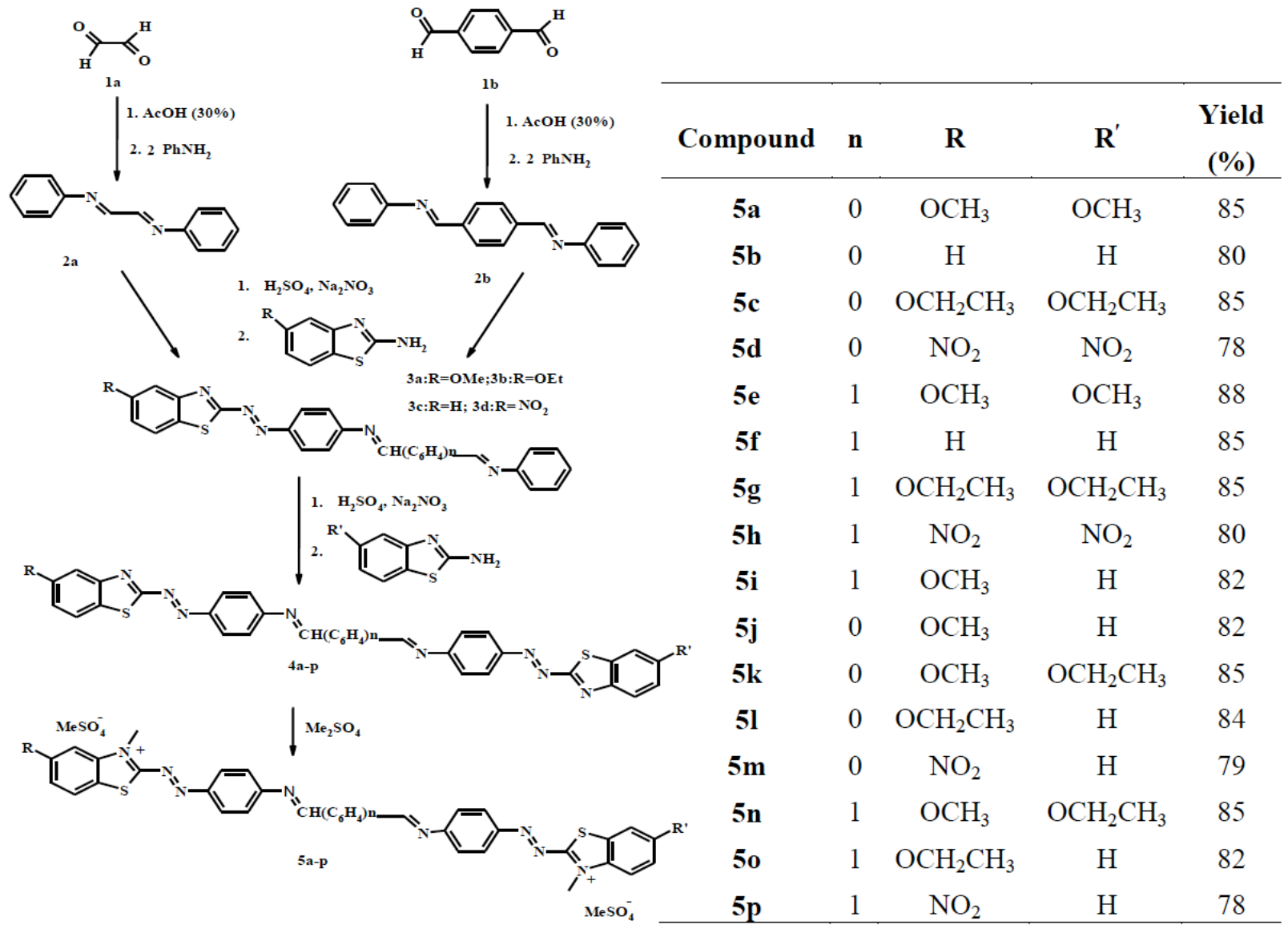

Scheme 1: Synthesis of dichromophoric benzothiazole-based cationic dyes $\mathbf{5 a - p .}$

wavelength, and were plotted for both of standards and cyanine dyes.

\section{Absorption Spectra}

In comparison with structures 4a-p with orange-red, red and purple color $\left(\lambda_{\max }: 462-523 \mathrm{~nm}\right)$, cationic dyes 5a-p revealed large bathochromic shifts $\left(\Delta \lambda_{\max }: 28-115\right.$ $\mathrm{nm})$ and showed violet to blue colors $\left(\lambda_{\max }: 551-588\right.$ $\mathrm{nm})$ with high molar absorption coefficients $(\varepsilon: 2.1-4.4$ $\times 10^{4} \mathrm{~L}^{\mathrm{M}} \mathrm{M}^{-1} \cdot \mathrm{cm}^{-1}$ ) in ethanol (See Table 1). Since, azo dyes are usually yellow, brown and red, so these violet and blue color azo dyes with great color strength can be very interesting achievement.

As it presented in Table 1, molar absorption coefficients of the derivatives with $n=1$ are usually higher than those for the same structure with $n=0$, and it might be resulted from development of a full conjugation structure in such cationic dyes.

In the symmetric structures with $\mathrm{n}=0$, the least molar absorption coefficient was $2.6 \times 10^{4} \mathrm{~L}^{\mathrm{M}} \mathrm{M}^{-1} . \mathrm{cm}^{-1}$ for $5 c\left(R=R^{\prime}=\mathrm{OEt}\right)$ and the highest molar absorption coefficient was $3.6 \times 10^{4}$ L.M ${ }^{-1} . \mathrm{cm}^{-1}$ for $5 \mathbf{d}\left(R=R^{\prime}=\mathrm{NO}_{2}\right)$.
In the symmetric structures with $\mathrm{n}=1$, the least molar absorption coefficient was $2.6 \times 10^{4} \mathrm{~L}^{\mathrm{L}} \mathrm{M}^{-1} . \mathrm{cm}^{-1}$ for $5 \mathrm{~g}$ $\left(\mathrm{R}=\mathrm{R}^{\prime}=\mathrm{OEt}\right)$ and the highest molar absorption

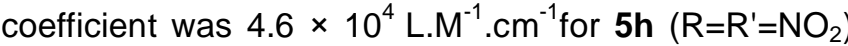
as well.

\section{Fluorescence Properties}

Each of dyes 5a-p was excited at a unique wavelength within range of 272-315 nm and showed fluorescence emission at a corresponding wavelength within range of 380-494 $\mathrm{nm}$ (Figure 1). Stokes shift $\left(v_{\mathrm{A}^{-}}\right.$ $\left.V_{F}\right)$, the important characteristic for fluorescent compounds, ${ }^{42}$ has been evaluated for the selected bischromophoric dyes.

The Stokes shift $\left(\mathrm{cm}^{-1}\right)$ indicates difference in properties and structure of a fluorophore between ground $\left(\mathrm{S}_{0}\right)$ and first excited $\left(\mathrm{S}_{1}\right)$ states, and could be calculated by Eq. (1).

$\left(V_{\mathrm{A}}-V_{\mathrm{F}}\right)=\left(1 / \lambda_{\mathrm{A}}-1 / \lambda_{\mathrm{F})} \times 10^{7}\right.$

The Stokes shifts values of the studied dyes were found among 7936-11480 $\mathrm{cm}^{-1}$ (Table 2). The 
Table 1: Summarized Absorption Spectral Data for the 5a-p Compounds Comparison with 4a-p

\begin{tabular}{|c|c|c|c|c|c|c|c|c|c|c|c|}
\hline 5 & n & $\mathbf{R}$ & $\mathbf{R}^{\prime}$ & $\lambda_{\text {max }}^{a}$ & $\varepsilon^{b} \times 10^{-4}$ & Color & 4 & $\lambda_{\text {max }}^{a}$ & $\varepsilon^{b} \times 10^{-4}$ & Color & $\Delta \lambda_{\max }$ \\
\hline $5 a$ & 0 & OMe & $\mathrm{OMe}$ & 588 & 3.1 & Blue & $4 a$ & 494 & 3.8 & Red & 94 \\
\hline $5 b$ & 0 & $\mathrm{H}$ & $\mathrm{H}$ & 571 & 2.9 & Blue & $4 b$ & 477 & 2.6 & Orange-red & 94 \\
\hline $5 c$ & 0 & OEt & OEt & 576 & 2.6 & Blue & $4 c$ & 496 & 2.3 & Red & 80 \\
\hline $5 d$ & 0 & $\mathrm{NO}_{2}$ & $\mathrm{NO}_{2}$ & 554 & 3.6 & Violet & $4 d$ & 521 & 2.5 & Purple & 33 \\
\hline $5 e$ & 1 & OMe & $\mathrm{OMe}$ & 573 & 3.2 & Blue & $4 e$ & 499 & 4.3 & Red & 74 \\
\hline $5 f$ & 1 & $\mathrm{H}$ & $\mathrm{H}$ & 571 & 4.2 & Blue & $4 f$ & 485 & 3.5 & Red & 86 \\
\hline $5 g$ & 1 & OEt & OEt & 578 & 2.6 & Blue & $4 \mathrm{~g}$ & 497 & 2.7 & Red & 81 \\
\hline $5 \mathrm{~h}$ & 1 & $\mathrm{NO}_{2}$ & $\mathrm{NO}_{2}$ & 551 & 4.6 & Violet & $4 h$ & 523 & 2.7 & Purple & 28 \\
\hline $5 i$ & 1 & OMe & $\mathrm{H}$ & 580 & 4.6 & Blue & $4 i$ & 493 & 4.4 & Red & 87 \\
\hline $5 j$ & 0 & OMe & $\mathrm{H}$ & 578 & 4.1 & Blue & $4 j$ & 465 & 3.3 & Orange & 113 \\
\hline $5 k$ & 0 & OMe & OEt & 584 & 3.1 & Blue & $4 k$ & 493 & 2.7 & Red & 91 \\
\hline $5 I$ & 0 & OEt & $\mathrm{H}$ & 577 & 3.4 & Blue & $4 \mid$ & 462 & 2.6 & Orange & 115 \\
\hline $5 m$ & 0 & $\mathrm{NO}_{2}$ & $\mathrm{H}$ & 565 & 3.4 & Indigo Blue & $4 m$ & 474 & 2.1 & Orange-red & 91 \\
\hline $5 n$ & 1 & OMe & OEt & 584 & 3.4 & Blue & $4 n$ & 494 & 3.5 & Red & 54 \\
\hline 50 & 1 & OEt & $\mathrm{H}$ & 579 & 3.6 & Blue & 40 & 468 & 2.7 & Orange & 85 \\
\hline $5 p$ & 1 & $\mathrm{NO}_{2}$ & $\mathrm{H}$ & 563 & 4.7 & Indigo Blue & $4 p$ & 482 & 2.9 & Red & 81 \\
\hline
\end{tabular}

All data are obtained in ethanol. $\lambda_{\max }$ : maximum absorption wavelength $(\mathrm{nm}) ; \varepsilon$ : corresponding molar absorption coefficient $\left(L . \mathrm{M}^{-1} . \mathrm{cm}^{-1}\right)$.

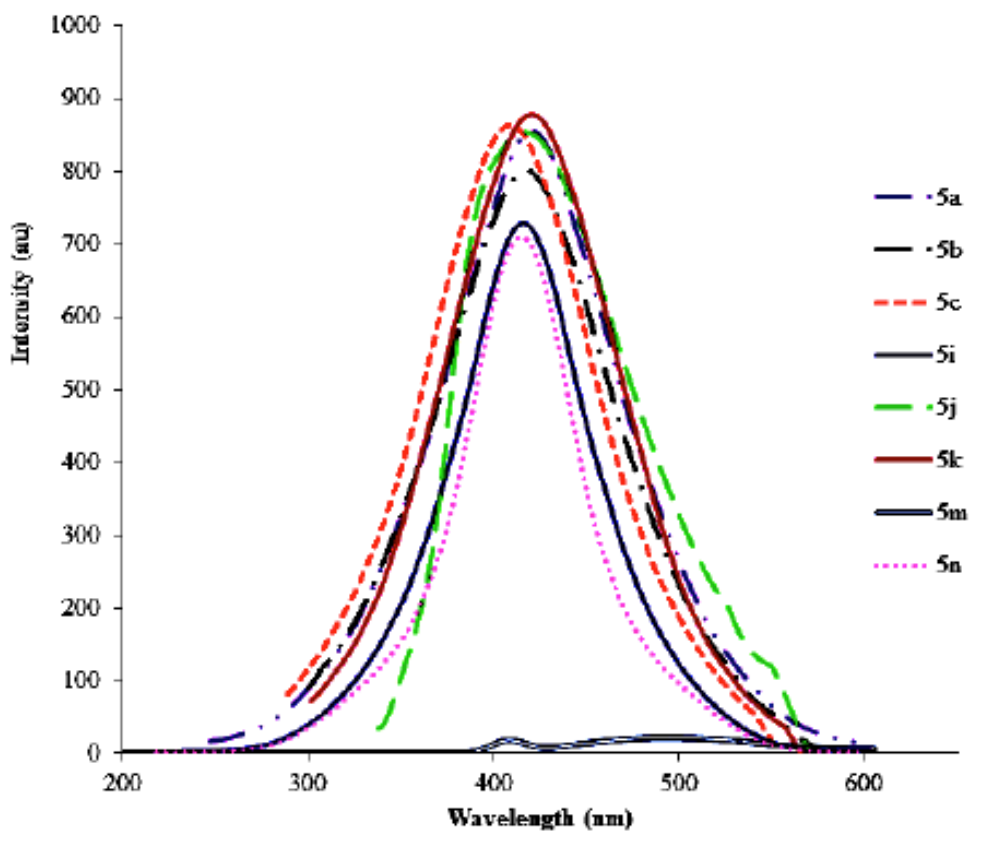

Figure 1: The fluorescence emission of the eight selected dyes in acetonitrile.

fluorescence quantum yield $\left(\Phi_{\mathrm{F}}\right)$, the ratio of the absorbed to the emitted photons during the process of fluorescence, of the selected cationic dyes in acetonitrile $\left(1 \times 10^{-4} \mathrm{~mol}^{-1} \mathrm{I}^{-1}\right)$ at $293 \mathrm{~K}$ were calculated using Eq. (2), and 1,1,4,4-tetraphenyl-1,3- butadiene $\left(\Phi_{\text {ref }}=0.7\right)$ was used as a reference.

$$
\Phi_{F}=\Phi_{\text {ref }}\left(\frac{S_{\text {sample }}}{S_{\text {ref }}}\right)\left(\frac{A_{\text {ref }}}{A_{\text {sample }}}\right)\left(\frac{n_{\text {sample }}^{2}}{n_{\text {ref }}^{2}}\right)
$$

$A_{\text {sample, }} S_{\text {sample, }}, n_{\text {sample }}$ and $A_{\text {ref, }}, S_{\text {ref, }}, n_{\text {ref }}$ are absorbance at the excitation wavelength, the integrated 
Table 2: Fluorescence Emission Characteristics of the Selected Bichromophoric Dyes in Acetonitrile at Room Temperature

\begin{tabular}{|c|c|c|c|c|c|c|c|c|c|}
\hline Compound & $\mathbf{n}$ & $\mathbf{R}$ & $\mathbf{R}^{\prime}$ & $\lambda_{\mathrm{ex}}(\mathrm{nm})$ & $\lambda_{e m}(n m)$ & $\begin{array}{l}V_{A^{-}} V_{F} \\
\left(\mathrm{~cm}^{-1}\right)\end{array}$ & $\begin{array}{l}\text { Intensity } \\
\text { (au) }\end{array}$ & $\Phi_{\mathrm{F}}$ & $E_{F}$ \\
\hline $5 a$ & 0 & OMe & OMe & 315 & 420 & 7936 & 855 & 0.13 & 0.097 \\
\hline $5 b$ & 0 & $\mathrm{H}$ & $\mathrm{H}$ & 272 & 417 & 12783 & 801 & 0.17 & 0.11 \\
\hline $5 c$ & 0 & OEt & OEt & 300 & 409 & 8883 & 862 & 0.14 & 0.10 \\
\hline $5 i$ & 1 & OMe & $\mathrm{H}$ & 350 & 416 & 4532 & 728 & 0.09 & 0.075 \\
\hline $5 j$ & 0 & OMe & $\mathrm{H}$ & 282 & 417 & 11480 & 853 & 0.18 & 0.12 \\
\hline $5 k$ & 0 & OMe & OEt & 315 & 420 & 7936 & 878 & 0.12 & 0.09 \\
\hline $5 m$ & 0 & $\mathrm{NO}_{2}$ & $\mathrm{H}$ & 404 & 494 & 4509 & 21.5 & 0.02 & 0.016 \\
\hline $5 n$ & 1 & OMe & OEt & 350 & 422 & 4874 & 689 & 0.08 & 0.066 \\
\hline
\end{tabular}

emission band area and the refractive index of the sample and reference, respectively.

As it shown in Table 2, the fluorescence quantum yield values of some selected dyes were 0.02-0.18. The structures with $\mathrm{NO}_{2}$ group showed very low fluorescence quantum yield.

The energy yields of fluorescence $E_{F}$, as conversion of energy to light efficiency [38, 39], for selected cationic dyes were also calculated by Eq. (3) and the results were reported in Table 2. The energy yields of fluorescence in this series were 0.016-0.12.

$E_{F}=\Phi_{F} \frac{\lambda_{A}}{\lambda_{F}}$

\section{Solvathochromic Effects}

Solvatochromism refers to an ability of a chemical compound to change the color due to change in solvent polarity and solvatochromic dye molecules have recently attracted much attention owing to their application as probes for the determination of solvent polarity [14, 42-45].

Solvatochromism lies at the basis of interaction between solvent and molecules' functional groups such as dipole moment change upon excitation from ground to excited state; therefore solvent-dependent spectral changes of solvatochromic dyes provide a precise sensor of changes in the surrounding environment [14, 42-45]. Solvatochromic behavior of cationic dyes 5 with symmetrical (5a-h) and asymmetrical (5i-p) structures were studied in different common solvents varying in polarity. The obtained results were compared with the spectroscopic behavior of their corresponded nonquaternized structures 4 . Some solvent parameters as $\varepsilon$ : dielectric constant; $\alpha$ : hydrogen bonding acceptor ability polarity scale; $\beta$ : hydrogen bonding donor ability polarity scale; $\pi^{*}$ : dipolarity/polarizability polarity scales for seven common used solvents are presented in Table $3[39,46]$.

Table 3: Solvents Dielectric Constant $(\varepsilon)$; Hydrogen Bonding Acceptor Ability Polarity Scale (a); Hydrogen Bonding Donor Ability Polarity Scale $(\beta)$; and Dipolarity/Polarizability Polarity Scale $\left(\pi^{*}\right)[39,46]$

\begin{tabular}{|c|c|c|c|c|}
\hline Solvent & $\boldsymbol{\varepsilon}$ & $\boldsymbol{\alpha}$ & $\boldsymbol{\beta}$ & $\boldsymbol{\pi}^{*}$ \\
\hline \hline $\mathrm{CHCl}_{3}$ & 4.81 & 0.44 & 0.00 & 0.76 \\
\hline $\mathrm{THF}$ & 7.58 & 0.00 & 0.55 & 0.55 \\
\hline Acetone & 21.01 & 0.08 & 0.48 & 0.62 \\
\hline $\mathrm{EtOH}$ & 24.30 & 0.86 & 0.75 & 0.54 \\
\hline $\mathrm{MeOH}$ & 33.70 & 0.98 & 0.66 & 0.60 \\
\hline $\mathrm{CH}_{3} \mathrm{CN}$ & 35.94 & 0.19 & 0.40 & 0.66 \\
\hline $\mathrm{DMSO}$ & 47.24 & 0.00 & 0.76 & 1.00 \\
\hline
\end{tabular}

Maximum absorption wavelengths of the cationic dyes 5 in two series of $n=0$ and $n=1$ in seven common solvents have been studied and the results are shown Table 4. The most solvatochromic shift for the first series, $n=0$, was $30 \mathrm{~nm}$ for $5 b\left(R=R^{\prime}=H\right)$. Hence, different solvents, such as chloroform, ethyl acetate, acetonitrile, and dimethylformamide, can be distinguished based on the maximum absorption wavelength of $\mathbf{5 b}$ and it can be used as indicator of the aforementioned solvents. Likewise, for the second series of these dyes, $n=1$, the most solvatochromic shift was $36 \mathrm{~nm}$ for $\mathbf{5 n}$ (Table 4 ).

\section{Correlation of Stokes Shifts with Solvent Polarity}

The fluorescence emission of most dyes was highly sensitive to polarity of different organic solvents. The 
Table 4: The Maximum Absorption Wavelengths, $\lambda_{\max }(\mathrm{nm})$, of 5 in the Different Solvents at Ambient Temperature

\begin{tabular}{|c|c|c|c|c|c|c|c|c|c|c|c|c|c|c|c|c|}
\hline \multirow[b]{2}{*}{ Solvent } & \multicolumn{8}{|c|}{$n=0$} & \multicolumn{8}{|c|}{$\mathrm{n}=1$} \\
\hline & $5 a$ & $5 b$ & $5 c$ & $5 d$ & $5 j$ & $5 k$ & $5 I$ & $5 \mathrm{~m}$ & $5 e$ & $5 f$ & $5 \mathrm{~g}$ & $5 \mathrm{~h}$ & $5 i$ & $5 n$ & 50 & $5 p$ \\
\hline $\mathrm{CHCl}_{3}$ & 581 & 579 & 577 & 555 & 570 & 575 & 569 & 563 & 576 & 576 & 575 & 578 & 571 & 587 & 576 & 561 \\
\hline THF & 594 & 589 & 582 & 559 & 574 & 578 & 570 & 562 & 584 & 584 & 582 & 585 & 575 & 594 & 576 & 560 \\
\hline Acetone & 584 & 591 & 580 & 560 & 576 & 579 & 575 & 566 & 580 & 580 & 578 & 582 & 576 & 558 & 580 & 564 \\
\hline $\mathrm{EtOH}$ & 588 & 571 & 576 & 554 & 578 & 584 & 577 & 565 & 573 & 573 & 571 & 578 & 580 & 584 & 579 & 563 \\
\hline $\mathrm{MeOH}$ & 588 & 566 & 576 & 554 & 573 & 578 & 574 & 564 & 578 & 578 & 575 & 575 & 575 & 582 & 578 & 561 \\
\hline $\mathrm{CH}_{3} \mathrm{CN}$ & 584 & 588 & 576 & 558 & 575 & 578 & 573 & 564 & 576 & 576 & 576 & 577 & 575 & 583 & 577 & 562 \\
\hline DMSO & 592 & 596 & 579 & 557 & 579 & 583 & 580 & 568 & 587 & 587 & 585 & 584 & 579 & 589 & 583 & 584 \\
\hline
\end{tabular}

fluorescence and Stokes shifts were showed a linear correlation, with the orientation polarizability $(\Delta \mathrm{f})$ and empirical polarity parameter $\mathrm{E}_{\mathrm{T}}(30)[42-45]$.

\section{Lippert-Mataga Equation}

Generally, Lippert-Mataga equation (4 and 5) describe how the stokes shift changes as a function of solvent properties [42-45].

$$
\begin{aligned}
& \Delta v=\frac{2 \Delta f}{4 \pi s_{o} h c a^{s}}\left(\mu_{e}-\mu_{g}\right)^{2}+C \\
& \Delta f=\frac{s-1}{2 s+1}-\frac{n^{2}-1}{2 n^{2}+1}
\end{aligned}
$$

Where $\varepsilon_{0}$ denotes the permittivity of the vacuum, $\Delta v$ explain the Stokes shift, $\mu_{\mathrm{e}}$ and $\mu_{g}$ are the dipole in the ground-state and in the excited-state geometry, respectively, h, c, a and $\Delta f$ are the Planck's constant, velocity of light in vacuum, Onsager cavity radius, and orientation polarizability, respectively. The LippertMataga correlations of the Stokes shifts of some derivatives of compounds $\mathbf{4}$ and $\mathbf{5}$ are illustrated in Figures 2 and 3. Poor linearity was found for all the studied compounds. The non-ionic structures of dyes $\mathbf{4}$ revealed positive slope i.e. positive solvatochromic effects to $\Delta f$ in the applied solvents as tetrahydrofuran, ethyl acetate, acetone, N,N-dimethylformamide, dimethyl sulfoxide, acetonitrile, dichloromethane, chloroform, ethanol, and methanol, but the cationic dyes 5 showed negative slope i.e. negative solvatochromic effects to $\Delta f$. Since, Stokes shift is caused by the effect of solvent on stability of exited state, current findings suggest that polar solvents more stabilize the dipole moment of the molecules in the ground state than the excited state, and it leads to blue shift or negative solvatochromic effect. Poor linear correlations were also observed for $\mathbf{5}$, suggesting that solute-solvent interactions in the excited states of the dyes are stronger than dipole-dipole interaction.

The Lippert-Mataga equation accounts for the general solvent effect and does not account for specific solvent-fluorophore interactions, hence the nonlinearity of the aforementioned correlations might be resulted from a specific solvent effect, presumably intermolecular hydrogen bonding between the solute and the solvent molecules [20].

\section{Reichardt-Dimroth's $E_{\mathrm{T}}(\mathrm{N})$}

Reichardt-Dimroth equation (Eq. 6) is another useful scale to correlate the solvent induced Stokes shift $\left(\mathrm{cm}^{-1}\right)$ with the molar electronic transition energies, i.e. the $E_{\mathrm{T}}(30)$ values $[40,41]$.

$E_{\mathrm{T}}(30)\left(\mathrm{kcal} \cdot \mathrm{mol}^{-1}\right)=h c N_{A} \tilde{\mathrm{v}}_{\max }=28591 / \lambda_{\max }$

where $h, c$, and $N_{A}$ are Planck's constant, speed of light, and Avogadro's constant, respectively, $\tilde{\mathrm{v}}_{\max }$ is the wavenumber $\left(\mathrm{cm}^{-1}\right)$, and $\lambda_{\max }$ is the wavelength $(\mathrm{nm})$ corresponding to the highest absorption band in the visible/near-IR region. The normalized $\mathrm{E}_{\mathrm{T}}{ }^{\mathrm{N}}$ scale could be defined as Eq. 7 .

$E_{T}^{N}=\frac{E_{T}(\text { solvent })-E_{T}\left(\mathrm{SiMe}_{4}\right)}{E_{T}(\text { water })-E_{T}\left(\mathrm{SiMe}_{4}\right)}=\frac{E_{T}(\text { solvent })-30.7}{32.4}$

A representative correlation for $4 c, 4 e, 5 c$ and $5 e$ and is depicted in Figure 3.

Nevertheless, no reasonable linear correlations were obtained with plotting the Stokes shift values against the Dimroth-Reichardt solvent parameters, as well. In general, increasing of solvent polarity was leaded to a red shift of fluorescence maxima for dyes 4c, 4e, 5c and 5e. The findings implicate that the interactions between solvent and dyes are more 
$5 \mathbf{i}$

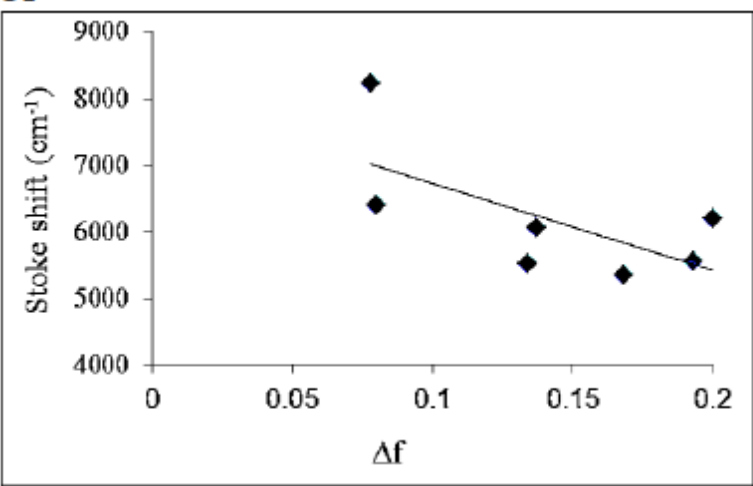

$5 p$

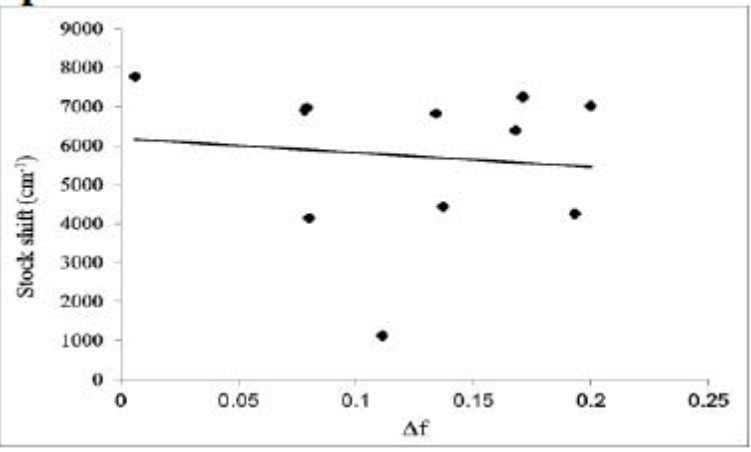

$4 \mathbf{i}$

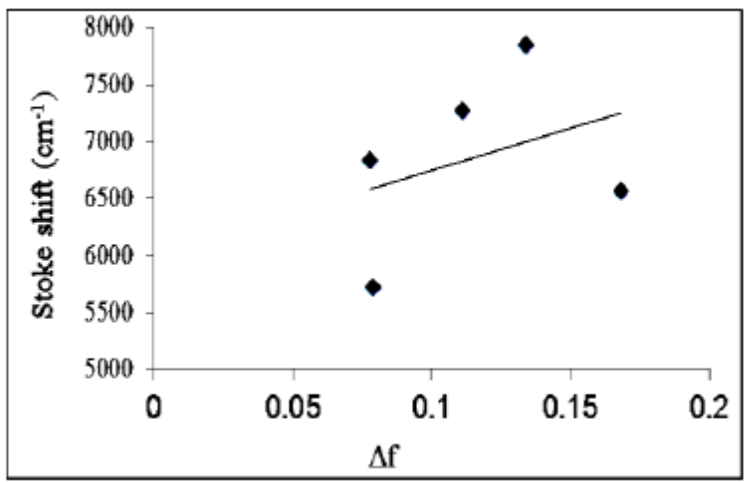

$4 \mathrm{p}$

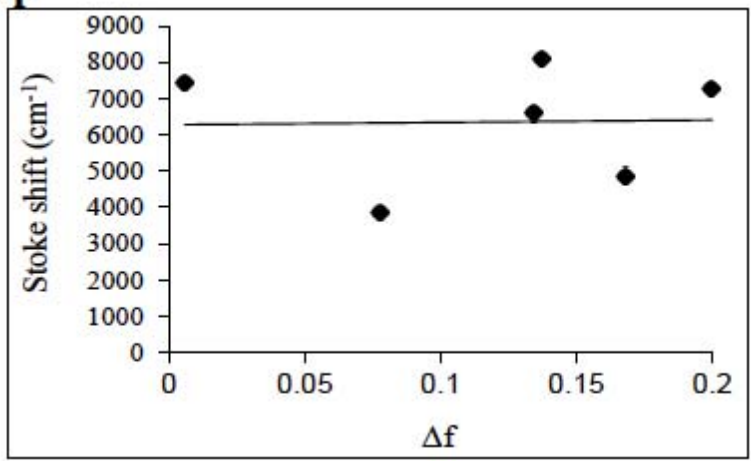

Figure 2: Lippert-Mataga plot showing Stokes shift as a function of solvent orientation polarizibility $(\Delta f)$ for $5 \mathbf{i}$ and $\mathbf{5 p}$ and $4 \mathbf{i}$ and $4 p$.

5c

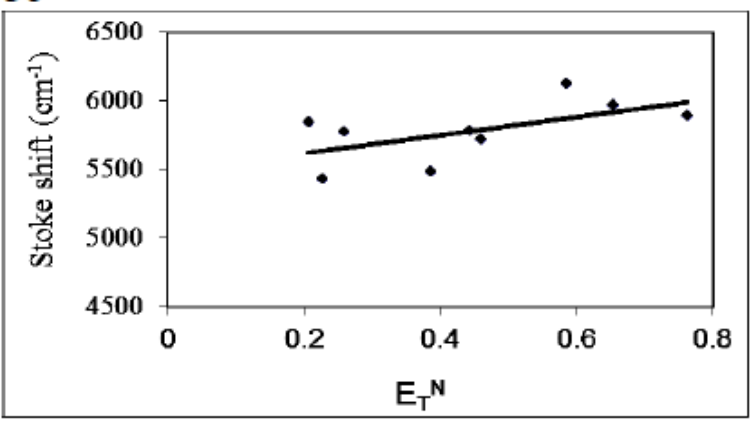

5 e

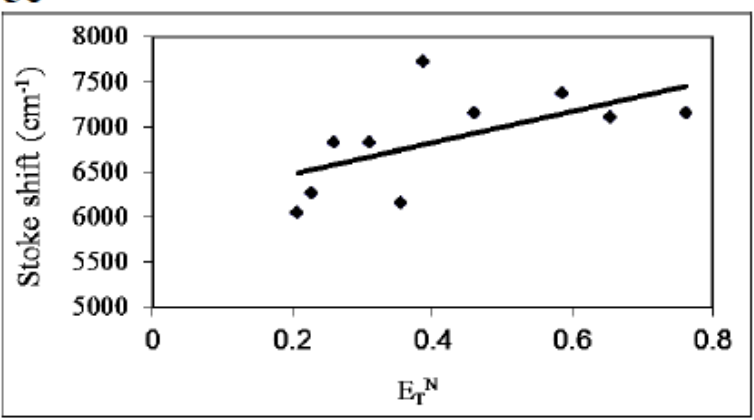

$4 c$

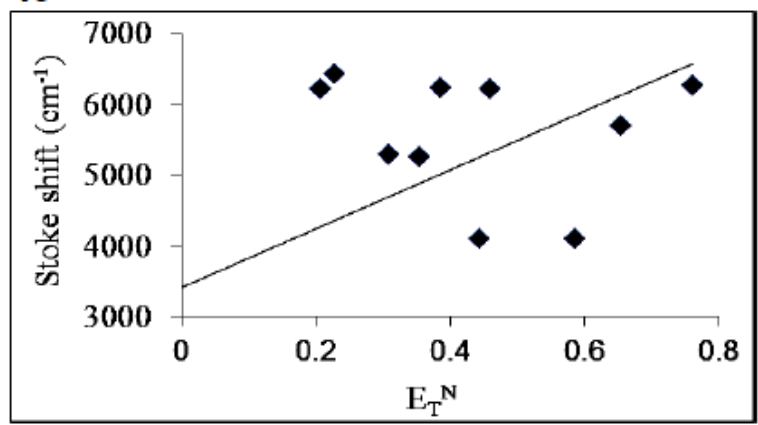

4e

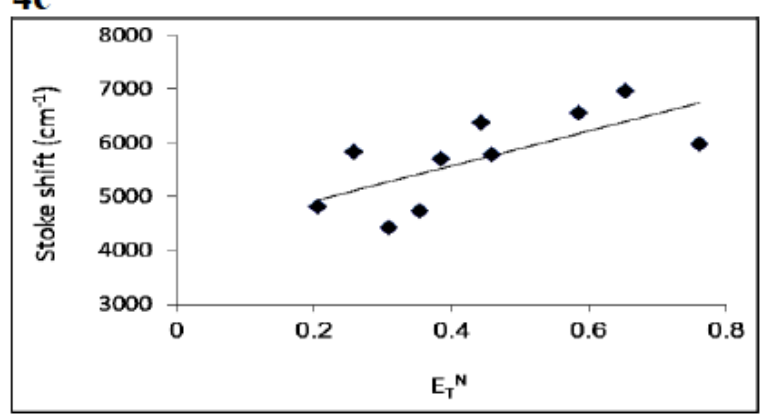

Figure 3: Relationship between the Stokes shift values $\left(\Delta v\right.$, Stokes shift, $\left.\mathrm{cm}^{-1}\right)$ and $E_{\top}(\mathrm{N})$ for $\mathbf{4 c}, \mathbf{4 e}, \mathbf{5 c}$, and $\mathbf{5 e}$ in tetrahydrofuran, ethyl acetate, acetone, $N, N$-dimethylformamide, dimethyl sulfoxide, acetonitrile; dichloromethane, chloroform, ethanol, Methanol. Excitation wavelength: $385 \mathrm{~nm}$. 
Table 5: The In Vitro Antibacterial Activities of the Selected Bichromophoric Dyes

\begin{tabular}{|c|c|c|c|c|c|}
\hline \multirow[b]{2}{*}{ Dye } & \multirow[b]{2}{*}{$\begin{array}{c}\text { Conc. } \\
(\mu \mathrm{g} / \mathrm{disc})\end{array}$} & \multicolumn{4}{|c|}{ Zone of inhibition $^{1}(\mathrm{~mm})$} \\
\hline & & $\begin{array}{c}\text { S. aureus } \\
\text { ATCC } 25923\end{array}$ & $\begin{array}{l}\text { S. epidermidis } \\
\text { ATCC } 12228\end{array}$ & $\begin{array}{c}\text { E. coli } \\
\text { ATCC } 25922\end{array}$ & $\begin{array}{c}\text { P. Aeruginosa } \\
\text { ATCC } 27853\end{array}$ \\
\hline \multirow[t]{2}{*}{$5 \mathrm{~g}$} & 60 & 15.0 & 11 & 0.0 & 0.0 \\
\hline & 30 & 13.0 & 8.0 & 0.0 & 0.0 \\
\hline \multirow[t]{3}{*}{$5 i$} & 60 & 11.0 & 0.0 & 0.0 & 0.0 \\
\hline & 30 & 12.0 & 0.0 & 0.0 & 0.0 \\
\hline & 15 & 9.0 & 0.0 & 0.0 & 0.0 \\
\hline $5 \mathrm{~m}$ & 60 & 9.0 & 7.0 & 0.0 & 0.0 \\
\hline
\end{tabular}

${ }^{1}$ Distilled water has been used as negative control.

complex than those which considered in the ReichardtDimroth equation or Lippert-Mataga equation.

\section{Antibacterial Effects}

Antibacterial effects of the synthesized cationic dyes were assessed against gram positive bacteria $S$. epidermidis and $S$. aureus and gram negative bacteria $E$. coli, and $P$. aeruginosa via the diffusion plate method. ${ }^{43}$ Paper disks $(r=2.5 \mathrm{~mm})$ containing a serial dilutions of the dyes, i.e. 1:1 to 1:128, was placed on a plate $(9 \mathrm{~cm}$ diameter) containing a solid bacterial growth medium (nutrient agar) which was heavily seeded with suspension of the selected bacterial strains. After 24 hours incubation at $37^{\circ} \mathrm{C}$, the inhibitory power of the dyes were measured based on the diameter of inhibition zone around the discs. Ampicillin and Ciprofloxacin were used as reference antibiotics to evaluate the relative potency of the given compounds under the same conditions. The results revealed that $\mathbf{5 g}, \mathbf{5 i}$ and $\mathbf{5 m}$ have mild antibacterial property against gram positive bacteria (Table $\mathbf{5}$ ).

\section{CONCLUSIONS}

Sixteen 2-aminobenzothiazoles based dichromophoric cationic azo dyes were synthesized and produced violet to blue color ( $\boldsymbol{\lambda}_{\max }$ : $551-588 \mathrm{~nm}$ ) with high molecular extinction coefficient $\left(2.6-4.7 \times 10^{4}\right.$ L.M $\left.\mathrm{M}^{-1} . \mathrm{cm}^{-1}\right)$. All of dyes showed strong fluorescence with quantum yield of $0.02-0.18$. Their unique excitation and emission wavelength were found at a broad range of 272-404 nm and 409-494 nm, respectively. The effects of solvents, with different polarity, were studied and negative slope, and negative solvatochromic effects to $\Delta f$, were found for cationic dyes 5 . Furthermore, mild antibacterial effects were observed against gram positive bacteria $S$. aureus, and $S$. epidermidis in different concentration of dyes.

\section{EXPERIMENTAL SECTION}

\section{General}

All Chemicals were purchased from Merck and used without further purification. Melting points were measured using a Buchi melting-point B-545 apparatus. ${ }^{1} \mathrm{H}$-NMR spectra was measured at 500 $\mathrm{MHz}$, by a Bruker 500-Avance Fourier transform (FT)NMR instrument with dimethyl sulfoxide (DMSO- $\mathrm{d}_{6}$ ) and $\mathrm{CDCl}_{3}$ as solvent. All chemical shifts $(\delta)$ are quoted in ppm and coupling constant $(J)$ in $\mathrm{Hz}$. The abbreviations used for the multiplicity of the NMR signals are: $\mathrm{s}=$ singlet, $\mathrm{d}=$ doublet, $\mathrm{t}=$ triplet, $\mathrm{q}=$ quartet, $d d=$ doublet of doublet, etc. FT-IR spectra were obtained with a Perkin-Elmer Spectrum One BX FTIR spectrometer. The UV/VIS spectra were recorded using a UV/VIS spectrophotometer, Multispec-1501 Shimadzu. Fluorescence spectra were taken on Fluorescence Spectrometer Perkin Elmer LS 55. Mass spectra were recorded on a Finnigan-Mat 8430 mass spectrometer operating at an ionization potential of 20 eV. 
General Procedure for the Preparation of Compounds 2a-b

Aniline $(0.02 \mathrm{~mol})$ was added drop wise to a stirred solution of glyoxal $1 \mathrm{a}(0.01 \mathrm{~mol})$ or terephthalaldehyde $1 \mathrm{~b}$ in acetic acid $30 \%(20 \mathrm{ml})$ at $5{ }^{\circ} \mathrm{C}$. The reaction mixture was stirred for 1 hour, filtered, and crystallized in water to afford the pure title compounds.

\section{General Procedure for the Preparation of Compounds 5a-p}

The synthetic pathway and properties of bis-azo dyes 4a-p, as disperse dyes, was achieved according to our previous reported $[39,46]$. Then to a magnetically stirred suspension of $4 a-p(10 \mathrm{mmol})$ and $\mathrm{NaHCO}_{3}(1.7 \mathrm{gr}, 20 \mathrm{mmol})$ in water $(4 \mathrm{ml})$, dimethyl sulfate $(4.4 \mathrm{ml}, 36 \mathrm{mmol})$ was added dropwise at $30{ }^{\circ} \mathrm{C}$. The reaction mixture was stirred at $60{ }^{\circ} \mathrm{C}$ for $2 \mathrm{~h}$. The reaction was monitored by TLC (chloroform: methanol, $8: 1)$. Afterward, the $\mathrm{pH}$ was adjusted to 4 by addition of $\mathrm{HCl}$ solution $(1 \mathrm{M})$. The precipitated dye was filtered and recrystallized three times in water to afford the pure title compounds.

(5a) Mono(5-methoxy-3-methyl-2-((E)-(4- ((E)-((E)-2((4-)(E)-(3--methyl-5-methoxybenzo[d]thiazol-3-ium2-yl)diazenyl)phenyl)imino)ethylidene)amino) phenyl)diazenyl)benzo[d]thiazol-3-ium mono(methyl sulfate)

Blue powder, yield (85\%), m.p. $>360^{\circ}$ C. IR $(\mathrm{KBr})$ $\left(\mathrm{V}_{\max }, \mathrm{Cm}^{-1}\right): 2932(\mathrm{CH}=), 1628(\mathrm{C}=\mathrm{N}), 1512(\mathrm{C}=\mathrm{C})$, $1294(\mathrm{C}-\mathrm{N}) ;{ }^{1} \mathrm{H}-\mathrm{NMR}\left(500 \mathrm{MHz}, \mathrm{DMSO}^{-\mathrm{d}_{6}}\right): \delta_{H} 3.86(\mathrm{~s}$, $6 \mathrm{H}, 2 \mathrm{OCH}_{3}, 4.13\left(\mathrm{~s}, 6 \mathrm{H}, 2 \mathrm{NCH}_{3}\right), 7.01\left(\mathrm{~d}, 2 \mathrm{H},{ }^{3} \mathrm{~J}_{\mathrm{HH}}\right.$ $8.15 \mathrm{~Hz}, 2 \mathrm{CH}), 7.20\left(\mathrm{~d}, 4 \mathrm{H},{ }^{3} J_{\mathrm{HH}} 7.83 \mathrm{~Hz}, 4 \mathrm{CH}\right), 7.32$ (d, $\left.4 \mathrm{H},{ }^{3} J_{\mathrm{HH}} 7.83 \mathrm{~Hz}, 4 \mathrm{CH}\right), 7.45\left(\mathrm{~d}, 2 \mathrm{H},{ }^{3} \mathrm{~J}_{\mathrm{HH}} 8.14 \mathrm{~Hz}, 2 \mathrm{CH}\right)$, $7.75\left(\mathrm{~d}, 2 \mathrm{H},{ }^{3} \mathrm{~J}_{\mathrm{HH}} 8.14 \mathrm{~Hz}, 2 \mathrm{CH}\right), 8.08(\mathrm{~s}, 2 \mathrm{H}, 2 \mathrm{CH}) . \mathrm{MS}$ $\mathrm{m} / \mathrm{z}(\%): 619\left(\mathrm{M}^{+}, 1\right), 605$ (14), 310 (34), 281 (14), 165 (12), 133 (100).

(5b) Mono(3-methyl-2-((E)-(4- ((E)-((E)-2-((4-((E)-(3-methyl-benzo[d]thiazol-3-ium-2-yl)diazenyl)phenyl) imino)ethylidene)amino)phenyl)diazenyl)benzo[d]th iazol-3-ium mono(methyl sulfate)

Blue powder, yield (80\%), m.p. 256-258 C. IR (KBr) $\left(\mathrm{V}_{\max }, \mathrm{Cm}^{-1}\right): 2939(\mathrm{CH}=), 1614(\mathrm{C}=\mathrm{N}), 1587(\mathrm{C}=\mathrm{C})$, $1271(\mathrm{C}-\mathrm{N}) .{ }^{1} \mathrm{H}-\mathrm{NMR}\left(500 \mathrm{MHz}, \mathrm{DMSO}-\mathrm{d}_{6}\right): \delta_{\mathrm{H}} 4.15(\mathrm{~s}$, $\left.6 \mathrm{H}, 2 \mathrm{NCH}_{3}\right), 6.89\left(\mathrm{~d}, 2 \mathrm{H},{ }^{3} \mathrm{~J}_{\mathrm{HH}} 8.09 \mathrm{~Hz}, 2 \mathrm{CH}\right), 7.07$ (d, $\left.4 \mathrm{H},{ }^{3} \mathrm{~J}_{\mathrm{HH}} 7.58 \mathrm{~Hz}, 4 \mathrm{CH}\right), 7.35\left(\mathrm{~d}, 4 \mathrm{H},{ }^{3} \mathrm{~J}_{\mathrm{HH}} 7.58 \mathrm{~Hz}, 4 \mathrm{CH}\right)$, $7.58\left(\mathrm{t}, 2 \mathrm{H},{ }^{3} \mathrm{~J}_{\mathrm{HH}} 8.30 \mathrm{~Hz}, 2 \mathrm{CH}\right), 7.64\left(\mathrm{t}, 2 \mathrm{H},{ }^{3} \mathrm{~J}_{\mathrm{HH}} 8.30\right.$ $\mathrm{Hz}, 2 \mathrm{CH}), 7.95\left(\mathrm{~d}, 2 \mathrm{H},{ }^{3} J_{\mathrm{HH}} 8.30 \mathrm{~Hz}, 2 \mathrm{CH}\right), 8.10$ (d, $\left.2 \mathrm{H},{ }^{3} \mathrm{~J}_{\mathrm{HH}} 8.30 \mathrm{~Hz}, 2 \mathrm{CH}\right) ; \mathrm{MS} \mathrm{m} / \mathrm{z}(\%): 559\left(\mathrm{M}^{+}, 2\right), 545$ (10), 280 (18), 252 (15), 165 (10), 133 (100). (5c) Mono(5-ethoxy-3-methyl-2-((E)-(4- ((E)-((E)-2((4-)(E)-(3--methyl-5-ethoxybenzo[d]thiazol-3-ium-2yl)diazenyl)phenyl)imino)ethylidene)amino)phenyl) diazenyl)benzo[d]thiazol-3-ium sulfate)

mono(methyl

Blue powder, yield (85\%), m.p. 227-229 C. IR (KBr) $\left(\mathrm{V}_{\max }, \mathrm{cm}^{-1}\right): 2929(\mathrm{CH}=), 1603(\mathrm{C}=\mathrm{N}), 1573(\mathrm{C}=\mathrm{C})$, $1261(\mathrm{C}-\mathrm{N}) .{ }^{1} \mathrm{H}-\mathrm{NMR}\left(500 \mathrm{MHz}, \mathrm{DMSO}-\mathrm{d}_{6}\right): \delta_{\mathrm{H}} 1.29(\mathrm{t}$, $\left.6 \mathrm{H},{ }^{3} \mathrm{~J}_{\mathrm{HH}} 6.86 \mathrm{~Hz}, 2 \mathrm{CH}_{3}\right), 4.12\left(\mathrm{q}, 4 \mathrm{H},{ }^{3} \mathrm{~J}_{\mathrm{HH}} 6.86 \mathrm{~Hz}, 2\right.$ $\left.\mathrm{OCH}_{2}\right), 4.15\left(\mathrm{~s}, 6 \mathrm{H}, 2 \mathrm{NCH}_{3}\right), 6.87\left(\mathrm{~d}, 2 \mathrm{H}^{3}{ }^{3} J_{\mathrm{HH}} 8.18 \mathrm{~Hz}\right.$, $2 \mathrm{CH}), 7.08\left(\mathrm{~d}, 4 \mathrm{H},{ }^{3} J_{\mathrm{HH}} 7.24 \mathrm{~Hz}, 4 \mathrm{CH}\right), 7.38\left(\mathrm{~d}, 4 \mathrm{H},{ }^{3} \mathrm{~J}_{\mathrm{HH}}\right.$ $7.24 \mathrm{~Hz}, 4 \mathrm{CH}), 7.86\left(\mathrm{~d}, 2 \mathrm{H},{ }^{3} J_{\mathrm{HH}} 8.38 \mathrm{~Hz}, 2 \mathrm{CH}\right), 7.98(\mathrm{~d}$, $\left.2 \mathrm{H},{ }^{3} \mathrm{~J}_{\mathrm{HH}} 8.38 \mathrm{~Hz}, 2 \mathrm{CH}\right), 8.07(\mathrm{~s}, 2 \mathrm{H}, 2 \mathrm{CH}) . \mathrm{MS} \mathrm{m} / \mathrm{z}(\%)$ : $647\left(\mathrm{M}^{+}, 1\right), 633$ (7), 324 (31), 296(15), 165 (12), 133 (100).

(5d) Mono(5-nitro-3-methyl-2-((E)-(4- ((E)-((E)-2-((4((E)-(3--methyl-5-nitrobenzo[d]thiazol-3-ium-2-yl) diazenyl)phenyl)imino)ethylidene)amino)phenyl)dia zenyl)benzo[d]thiazol-3-ium mono(methyl sulfate)

Indigo Blue powder, yield (78\%), m.p. 2247-249 C. IR $(\mathrm{KBr})\left(\mathrm{V}_{\max }, \mathrm{Cm}^{-1}\right): 2928(\mathrm{CH}=), 1632(\mathrm{C}=\mathrm{N}), 1519$ $(\mathrm{C}=\mathrm{C}), 1292(\mathrm{C}-\mathrm{N}) ;{ }^{1} \mathrm{H}-\mathrm{NMR}\left(500 \mathrm{MHz}, \mathrm{DMSO}-\mathrm{d}_{6}\right): \delta_{\mathrm{H}}$ $6.82\left(\mathrm{~d}, 2 \mathrm{H},{ }^{3} J_{\mathrm{HH}} 8.22 \mathrm{~Hz}, 2 \mathrm{CH}\right), 7.12\left(\mathrm{~d}, 4 \mathrm{H},{ }^{3} J_{\mathrm{HH}} 7.72\right.$ $\mathrm{Hz}, 4 \mathrm{CH}), 7.44\left(\mathrm{~d}, 4 \mathrm{H},{ }^{3} \mathrm{~J}_{\mathrm{HH}} 7.42 \mathrm{~Hz}, 4 \mathrm{CH}\right), 8.12$ (d, $\left.2 \mathrm{H},{ }^{3} \mathrm{~J}_{\mathrm{HH}} 8.05 \mathrm{~Hz}, 2 \mathrm{CH}\right), 8.25\left(\mathrm{~d}, 2 \mathrm{H},{ }^{3} \mathrm{~J}_{\mathrm{HH}} 8.05 \mathrm{~Hz}, 2 \mathrm{CH}\right)$, 8.41 (s, 2H, $2 \mathrm{CH})$. MS m/z (\%): $649\left(\mathrm{M}^{+}, 3\right), 635$ (9), 325 (26), 297 (12), 165 (14), 133 (100).

(5e) Mono(5-methoxy-3-methyl-2-((E)-(4- ((E)-(4-((E)((4-)((E)-(3--methyl-5-mthoxybenzo[d]thiazol-3-ium2-yl)diazenyl)phenyl)imino)methyl)benzylidene) amino)phenyl)diazenyl)benzo[d]thiazol-3-ium mono(methyl sulfate)

Blue powder, yield (88\%), m.p. 315-317 ${ }^{\circ} \mathrm{C}$. IR (KBr) $\left(\mathrm{V}_{\max }, \mathrm{Cm}^{-1}\right): 2961(\mathrm{CH}=), 1632(\mathrm{C}=\mathrm{N}), 1574(\mathrm{C}=\mathrm{C}), 1288$ $(\mathrm{C}-\mathrm{N}) ;{ }^{1} \mathrm{H}-\mathrm{NMR}\left(500 \mathrm{MHz}, \mathrm{DMSO}-\mathrm{d}_{6}\right): \delta_{\mathrm{H}} 3.98(\mathrm{~s}, 6 \mathrm{H}$, $2 \mathrm{OCH}_{3}, 4.11\left(\mathrm{~s}, 6 \mathrm{H}, 2 \mathrm{NCH}_{3}\right), 7.03(\mathrm{~s}, 4 \mathrm{H}, 4 \mathrm{CH}), 7.36$ (d, $\left.4 \mathrm{H}^{3}{ }^{3} J_{\mathrm{HH}} 7.57 \mathrm{~Hz}, 4 \mathrm{CH}\right), 7.55\left(\mathrm{~d}, 4 \mathrm{H},{ }^{3} J_{\mathrm{HH}} 7.57 \mathrm{~Hz}\right.$, $4 \mathrm{CH}), 7.99\left(\mathrm{~d}, 2 \mathrm{H},{ }^{3} \mathrm{~J}_{\mathrm{HH}} 8.12 \mathrm{~Hz}, 2 \mathrm{CH}\right), 8.11\left(\mathrm{~d}, 2 \mathrm{H},{ }^{3} \mathrm{~J}_{\mathrm{HH}}\right.$ $8.12 \mathrm{~Hz}, 2 \mathrm{CH}), 8.28(\mathrm{~s}, 2 \mathrm{H}, 2 \mathrm{CH}), 8.50(\mathrm{~s}, 2 \mathrm{H}, 2 \mathrm{CH})$. MS m/z (\%): $695\left(\mathrm{M}^{+}, 2\right), 681$ (5), 348 (12), 241 (42), 106 (17), 133 (100).

(5f) Mono(3-methyl-2-((E)-(4- ((E)-(4-((E)-((4-)((E)-(3-methyl-benzo[d]thiazol-3-ium-2-yl)diazenyl)phenyl) imino)methyl)benzylidene)amino)phenyl)diazenyl)b enzo[d]thiazol-3-ium mono(methyl sulfate)

Blue powder, yield (85\%), m.p. 291-293 C. IR (KBr) $\left(\mathrm{V}_{\max }, \mathrm{Cm}^{-1}\right): 2958(\mathrm{CH}=), 1605(\mathrm{C}=\mathrm{N}), 1568(\mathrm{C}=\mathrm{C})$, $1284(\mathrm{C}-\mathrm{N}) ;{ }^{1} \mathrm{H}-\mathrm{NMR}\left(500 \mathrm{MHz}, \mathrm{DMSO}-\mathrm{d}_{6}\right): \delta_{\mathrm{H}} 4.13(\mathrm{~s}$, $\left.6 \mathrm{H}, 2 \mathrm{NCH}_{3}\right), 7.15(\mathrm{~s}, 4 \mathrm{H}, 4 \mathrm{CH}), 7.53\left(\mathrm{~d}, 4 \mathrm{H},{ }^{3} J_{\mathrm{HH}} 7.49\right.$ $\mathrm{Hz}, 4 \mathrm{CH}), 7.83$ (d, $\left.4 \mathrm{H},{ }^{3} \mathrm{~J}_{\mathrm{HH}} 7.49 \mathrm{~Hz}, 4 \mathrm{CH}\right), 7.97$ (t, $\left.2 \mathrm{H},{ }^{3} \mathrm{~J}_{\mathrm{HH}} 8.52 \mathrm{~Hz}, 2 \mathrm{CH}\right), 8.02\left(\mathrm{t}, 2 \mathrm{H},{ }^{3} \mathrm{~J}_{\mathrm{HH}} 8.52 \mathrm{~Hz}, 2 \mathrm{CH}\right.$ ), 
$8.09\left(\mathrm{~d}, 2 \mathrm{H},{ }^{3} \mathrm{~J}_{\mathrm{HH}} 8.52 \mathrm{~Hz}, 2 \mathrm{CH}\right), 8.23\left(\mathrm{~d}, 2 \mathrm{H},{ }^{3} \mathrm{~J}_{\mathrm{HH}} 8.52\right.$ $\mathrm{Hz}, 2 \mathrm{CH}), 8.49(\mathrm{~s}, 2 \mathrm{H}, 2 \mathrm{CH})$. MS $m / z(\%): 635\left(\mathrm{M}^{+}, 3\right)$, 621 (10), 318 (18), 241 (16), 133 (100).

(5g) Mono(5-ethoxy-3-methyl-2-((E)-(4- ((E)-(4-)((E)((4-)(E)-(3--methyl-5-ethoxybenzo[d]thiazol-3-ium-2yl)diazenyl)phenyl)imino)methyl)benzylidene) amino)phenyl)diazenyl)benzo[d]thiazol-3-ium mono (methyl sulfate)

Blue powder, yield (85\%), m.p. 278-280 C. IR (KBr) $\left(\mathrm{V}_{\max }, \mathrm{Cm}^{-1}\right): 2932(\mathrm{CH}=), 1651(\mathrm{C}=\mathrm{N}), 1587(\mathrm{C}=\mathrm{C}) 1274$ $(\mathrm{C}-\mathrm{N}) ;{ }^{1} \mathrm{H}-\mathrm{NMR}\left(500 \mathrm{MHz}\right.$, DMSO-d 6 ): $\delta_{\mathrm{H}} 1.48(\mathrm{t}$, $\left.6 \mathrm{H},{ }^{3} J_{\mathrm{HH}} 6.82 \mathrm{~Hz}, 2 \mathrm{CH}_{3}\right), 4.11$ (q, $4 \mathrm{H},{ }^{3} J_{\mathrm{HH}} 6.82 \mathrm{~Hz}$, $\left.2 \mathrm{OCH}_{2}\right), 4.15\left(\mathrm{~s}, 6 \mathrm{H}, 2 \mathrm{NCH}_{3}\right), 7.12(\mathrm{~s}, 4 \mathrm{H}, 4 \mathrm{CH}), 7.32$ (d, $\left.4 \mathrm{H},{ }^{3} J_{\mathrm{HH}} 7.59 \mathrm{~Hz}, 4 \mathrm{CH}\right), 7.57\left(\mathrm{~d}, 4 \mathrm{H},{ }^{3} \mathrm{~J}_{\mathrm{HH}} 7.59 \mathrm{~Hz}\right.$, $4 \mathrm{CH}), 7.96\left(\mathrm{~d}, 2 \mathrm{H},{ }^{3} \mathrm{~J}_{\mathrm{HH}} 8.24 \mathrm{~Hz}, 2 \mathrm{CH}\right), 8.07\left(\mathrm{~d}, 2 \mathrm{H},{ }^{3} J_{\mathrm{HH}}\right.$ $8.24 \mathrm{~Hz}, 2 \mathrm{CH}), 8.17(\mathrm{~s}, 4 \mathrm{H}, 4 \mathrm{CH}), 8.31(\mathrm{~s}, 2 \mathrm{H}, 2 \mathrm{CH})$, $8.61(\mathrm{~s}, 2 \mathrm{H}, 2 \mathrm{CH})$. MS m/z (\%): $723\left(\mathrm{M}^{+}, 2\right), 709(7)$, 362 (10), 241 (32), 133 (100).

(5h) Mono(5-nitro-3-methyl-2-((E)-(4- ((E)-(4-((E)-((4((E)-(3--methyl-5-nitrobenzo[d]thiazol-3-ium-2-yl) diazenyl)phenyl)imino)methyl)benzylidene)amino) phenyl)diazenyl)benzo[d]thiazol-3-ium mono(methyl sulfate)

Indigo Blue powder, yield (80\%), m.p. 264-266 C. IR $(\mathrm{KBr})\left(\mathrm{V}_{\max }, \mathrm{Cm}^{-1}\right): 2936(\mathrm{CH}=), 1641(\mathrm{C}=\mathrm{N}), 1592$ $(\mathrm{C}=\mathrm{C}), 1283(\mathrm{C}-\mathrm{N}) ;{ }^{1} \mathrm{H}-\mathrm{NMR}\left(500 \mathrm{MHz}\right.$, DMSO-d $\left.\mathrm{d}_{6}\right): \delta_{\mathrm{H}}$ $4.10\left(\mathrm{~s}, 6 \mathrm{H}, 2 \mathrm{NCH}_{3}\right), 7.05(\mathrm{~s}, 4 \mathrm{H}, 4 \mathrm{CH}), 7.28(\mathrm{~d}, 4 \mathrm{H}$, $\left.{ }^{3} J_{\mathrm{HH}} 7.73 \mathrm{~Hz}, 4 \mathrm{CH}\right), 7.78$ (d, $4 \mathrm{H},{ }^{3} J_{\mathrm{HH}} 7.73 \mathrm{~Hz}, 4 \mathrm{CH}$ ), $8.22\left(\mathrm{~d}, 2 \mathrm{H},{ }^{3} \mathrm{~J}_{\mathrm{HH}} 8.35 \mathrm{~Hz}, 2 \mathrm{CH}\right), 8.34\left(\mathrm{~d}, 2 \mathrm{H},{ }^{3} \mathrm{~J}_{\mathrm{HH}} 8.35\right.$ $\mathrm{Hz}, 2 \mathrm{CH}), 8.52(\mathrm{~s}, 2 \mathrm{H}, 2 \mathrm{CH}), 8.59(\mathrm{~s}, 2 \mathrm{H}, 2 \mathrm{CH}) . \mathrm{MS}$ $\mathrm{m} / \mathrm{z}(\%): 725\left(\mathrm{M}^{+}, 3\right), 711$ (7), 363 (19), 241 (32), 133 $(100)$.

(5i) Mono(5-methoxy-3-methyl-2-((E)-(4- ((E)-(4-)(E)((4-((E)-(3--methyl-benzo[d]thiazol-3-ium-2-yl) diazenyl)phenyl)imino)methyl)benzylidene)amino) phenyl)diazenyl)benzo[d]thiazol-3-ium mono(methyl sulfate)

Blue powder, yield (82\%), m.p. 315-317 ${ }^{\circ} \mathrm{C}$. IR $(\mathrm{KBr})$ $\left(\mathrm{V}_{\max }, \mathrm{Cm}^{-1}\right): 2979(\mathrm{CH}=), 1617(\mathrm{C}=\mathrm{N}), 1574(\mathrm{C}=\mathrm{C})$, $1283(\mathrm{C}-\mathrm{N}) ;{ }^{1} \mathrm{H}-\mathrm{NMR}\left(500 \mathrm{MHz}, \mathrm{DMSO}-\mathrm{d}_{6}\right): \delta_{\mathrm{H}} 3.96(\mathrm{~s}$, $\left.3 \mathrm{H}, \mathrm{OCH}_{3}\right), 4.12\left(\mathrm{~s}, 6 \mathrm{H}, 2 \mathrm{NCH}_{3}\right), 7.06(\mathrm{~s}, 4 \mathrm{H}, 4 \mathrm{CH})$, 7.38-8.38 (m, 15H, Ar), $8.52(\mathrm{~s}, 2 \mathrm{H}, 2 \mathrm{CH})$. MS m/z (\%): $665\left(\mathrm{M}^{+}, 2\right), 651$ (4), 348 (11), 318 (14), 241 (27), 133 (100).

(5j) Mono(5-methoxy-3-methyl-2-((E)-(4- ((E)-((E)-2((4-)(E)-(3--methyl-benzo[d]thiazol-3-ium-2-yl) diazenyl)phenyl)imino)ethylidene)amino)phenyl)dia zenyl)benzo[d]thiazol-3-ium mono(methyl sulfate)

Blue powder, yield (95\%), m.p. 293-295 C. IR ( $\mathrm{KBr})$ $\left(\mathrm{V}_{\max }, \mathrm{Cm}^{-1}\right): 2933(\mathrm{CH}=), 1609(\mathrm{C}=\mathrm{N}), 1585(\mathrm{C}=\mathrm{C}), 1277$
$(\mathrm{C}-\mathrm{N}) ;{ }^{1} \mathrm{H}-\mathrm{NMR}\left(500 \mathrm{MHz}, \mathrm{DMSO}-\mathrm{d}_{6}\right): \delta_{\mathrm{H}} 3.85(\mathrm{~s}, 3 \mathrm{H}$, $\left.\mathrm{OCH}_{3}\right), 4.17\left(\mathrm{~s}, 6 \mathrm{H}, 2 \mathrm{NCH}_{3}\right), 6.89\left(\mathrm{~d}, 2 \mathrm{H},{ }^{3} \mathrm{~J}_{\mathrm{HH}} 8.85 \mathrm{~Hz}\right.$, $2 \mathrm{CH}), 7.01-8.13(\mathrm{~m}, \mathrm{Ar}, 15 \mathrm{H})$. MS m/z (\%): $589\left(\mathrm{M}^{+}, 2\right)$, 310 (15), 280 (9), 165 (14), 133 (100).

(5k) Mono(5-ethoxy-3-methyl-2-((E)-(4- ((E)-((E)-2((4-)(E)-(3--methyl-5-methoxybenzo[d]thiazol-3-ium2-yl)diazenyl)phenyl)imino)ethylidene)amino) phenyl)diazenyl)benzo[d]thiazol-3-ium mono(methyl sulfate)

Blue powder, yield (85\%), m.p. $>360$ C. IR $(\mathrm{KBr})$ $\left(\mathrm{V}_{\max }, \mathrm{Cm}^{-1}\right): 2928(\mathrm{CH}=), 1623(\mathrm{C}=\mathrm{N}), 1536(\mathrm{C}=\mathrm{C})$, $1292(\mathrm{C}-\mathrm{N}) ;{ }^{1} \mathrm{H}-\mathrm{NMR}\left(500 \mathrm{MHz}, \mathrm{DMSO}-\mathrm{d}_{6}\right): \delta_{\mathrm{H}} 1.51(\mathrm{t}$, $\left.3 \mathrm{H},{ }^{3} \mathrm{~J}_{\mathrm{HH}} 6.71 \mathrm{~Hz}, \mathrm{CH}_{3}\right), 3.93$ (s, 3H, $\left.\mathrm{OCH}_{3}\right), 4.11$ (q, $\left.2 \mathrm{H},{ }^{3} \mathrm{~J}_{\mathrm{HH}} 6.71 \mathrm{~Hz}, \mathrm{OCH}_{2}\right), 4.16\left(\mathrm{~s}, 6 \mathrm{H}, 2 \mathrm{NCH}_{3}\right), 6.91$ (d, $\left.2 \mathrm{H},{ }^{3} J_{\mathrm{HH}} 8.36 \mathrm{~Hz}, 2 \mathrm{CH}\right), 6.98-8.24(\mathrm{~m}, 14 \mathrm{H}, \mathrm{Ar}) . \mathrm{MS} \mathrm{m} / \mathrm{z}$ (\%): $633\left(\mathrm{M}^{+}, 3\right), 619(5), 324$ (10), 310 (15), $165(22)$, $133(100)$.

(5I) Mono(5-ethoxy-3-methyl-2-((E)-(4- ((E)-((E)-2-((4((E)-(3--methyl-benzo[d]thiazol-3-ium-2-yl)diazenyl) phenyl)imino)ethylidene)amino)phenyl)diazenyl)be nzo[d]thiazol-3-ium mono(methyl sulfate)

Blue powder, yield (84\%), m.p. 305-307 C. IR (KBr) $\left(\mathrm{V}_{\max }, \mathrm{Cm}^{-1}\right): 2938(\mathrm{CH}=), 1624(\mathrm{C}=\mathrm{N}), 1529(\mathrm{C}=\mathrm{C})$, $1295(\mathrm{C}-\mathrm{N}) .{ }^{1} \mathrm{H}-\mathrm{NMR}\left(500 \mathrm{MHz}, \mathrm{DMSO}-\mathrm{d}_{6}\right): \delta_{\mathrm{H}} 1.53(\mathrm{t}$, $\left.3 \mathrm{H},{ }^{3} J_{\mathrm{HH}} 6.94 \mathrm{~Hz}, \mathrm{CH}_{3}\right), 4.11$ (q, $2 \mathrm{H},{ }^{3} J_{\mathrm{HH}} 6.94 \mathrm{~Hz}$, $\left.\mathrm{OCH}_{2}\right), 4.14\left(\mathrm{~s}, 6 \mathrm{H}, 2 \mathrm{NCH}_{3}\right), 6.91\left(\mathrm{~d}, 2 \mathrm{H},{ }^{3} \mathrm{~J}_{\mathrm{HH}} 8.47 \mathrm{~Hz}\right.$, $2 \mathrm{CH}), 7.04-8.28(\mathrm{~m}, 15 \mathrm{H}, \mathrm{Ar})$. MS $\mathrm{m} / \mathrm{z}(\%): 603\left(\mathrm{M}^{+}\right.$, 1), 589 (10); 324 (14), 280 (22), 165 (26), 133 (100).

(5m) Mono(5-nitro-3-methyl-2-((E)-(4- ((E)-((E)-2-((4((E)-(3--methyl-benzo[d]thiazol-3-ium-2-yl)diazenyl) phenyl)imino)ethylidene)amino)phenyl)diazenyl)be nzo[d]thiazol-3-ium mono(methyl sulfate)

Indigo Blue powder, yield (79\%), m.p. 229-231 $\mathrm{C}$. IR $(\mathrm{KBr})\left(\mathrm{V}_{\max }, \mathrm{Cm}^{-1}\right): 2934(\mathrm{CH}=), 1619(\mathrm{C}=\mathrm{N}), 1574$ $(\mathrm{C}=\mathrm{C}), 1289(\mathrm{C}-\mathrm{N}) ;{ }^{1} \mathrm{H}-\mathrm{NMR}\left(500 \mathrm{MHz}, \mathrm{DMSO}-\mathrm{d}_{6}\right): \delta_{\mathrm{H}}$ $4.18\left(\mathrm{~s}, 6 \mathrm{H}, 2 \mathrm{NCH}_{3}\right), 6.94\left(\mathrm{~d}, 2 \mathrm{H},{ }^{3} \mathrm{~J}_{\mathrm{HH}} 8.75 \mathrm{~Hz}, 2 \mathrm{CH}\right)$, $7.12\left(\mathrm{~d}, 2 \mathrm{H},{ }^{3} \mathrm{~J}_{\mathrm{HH}} 6.64 \mathrm{~Hz}, 2 \mathrm{CH}\right), 7.37\left(\mathrm{~d}, 2 \mathrm{H},{ }^{3} \mathrm{~J}_{\mathrm{HH}} 6.64\right.$ $\mathrm{Hz}, 2 \mathrm{CH}), 7.52$ (d, 2H, $\left.{ }^{3} J_{\mathrm{HH}} 6.64 \mathrm{~Hz}, 2 \mathrm{CH}\right), 7.71$ (d, $\left.2 \mathrm{H},{ }^{3} J_{\mathrm{HH}} 6.64 \mathrm{~Hz}, 2 \mathrm{CH}\right), 7.82\left(\mathrm{t}, 1 \mathrm{H},{ }^{3} J_{\mathrm{HH}} 8.32 \mathrm{~Hz}, \mathrm{CH}\right)$, $8.01\left(\mathrm{t}, 1 \mathrm{H},{ }^{3} \mathrm{~J}_{\mathrm{HH}} 8.32 \mathrm{~Hz}, \mathrm{CH}\right), 8.08\left(\mathrm{~d}, 1 \mathrm{H},{ }^{3} \mathrm{~J}_{\mathrm{HH}} 8.32 \mathrm{~Hz}\right.$, $\mathrm{CH}), 8.14\left(\mathrm{~d}, 1 \mathrm{H},{ }^{3} \mathrm{~J}_{\mathrm{HH}} 8.32 \mathrm{~Hz}, \mathrm{CH}\right), 8.26\left(\mathrm{~d}, 1 \mathrm{H},{ }^{3} \mathrm{~J}_{\mathrm{HH}}\right.$ $8.32 \mathrm{~Hz}, \mathrm{CH}) ; 8.34\left(\mathrm{~d}, 1 \mathrm{H},{ }^{3} \mathrm{~J}_{\mathrm{HH}} 8.32 \mathrm{~Hz}, \mathrm{CH}\right) ; 8.61$ (s, $1 \mathrm{H}, \mathrm{CH})$. MS m/z (\%): $604\left(\mathrm{M}^{+}, 1\right), 590$ (12), 325 (11), 280 (16), 165 (24), 133 (100).

(5n) Mono(5-ethoxy-3-methyl-2-((E)-(4- ((E)-(4-)(E)((4-)(E)-(3--methyl-5-methoxybenzo[d]thiazol-3-ium2-yl)diazenyl)phenyl)imino)methyl)benzylidene) amino)phenyl)diazenyl)benzo[d]thiazol-3-ium mono(methyl sulfate)

Blue powder, yield (85\%), m.p>360 C. IR (KBr) $\left(\mathrm{V}_{\max }, \mathrm{Cm}^{-1}\right): 2954(\mathrm{CH}=), 1641(\mathrm{C}=\mathrm{N}), 1585(\mathrm{C}=\mathrm{C})$, 
$1274(\mathrm{C}-\mathrm{N}) ;{ }^{1} \mathrm{H}-\mathrm{NMR}\left(500 \mathrm{MHz}, \mathrm{DMSO}-\mathrm{d}_{6}\right): \delta_{\mathrm{H}} 1.50(\mathrm{t}$, $\left.3 \mathrm{H},{ }^{3} \mathrm{~J}_{\mathrm{HH}} 6.74 \mathrm{~Hz}, \mathrm{CH}_{3}\right), 3.99\left(\mathrm{~s}, 3 \mathrm{H}, \mathrm{OCH}_{3}\right), 4.11$ (q, $\left.2 \mathrm{H},{ }^{3} \mathrm{~J}_{\mathrm{HH}} 6.74 \mathrm{~Hz}, \mathrm{OCH}_{2}\right), 4.16\left(\mathrm{~s}, 6 \mathrm{H}, 2 \mathrm{NCH}_{3}\right), 7.11$ (s, $4 \mathrm{H}, 4 \mathrm{CH}), 7.35-8.37(\mathrm{~m}, 14 \mathrm{H}, \mathrm{Ar}), 8.54(\mathrm{~s}, 2 \mathrm{H}, 2 \mathrm{CH})$. MS m/z (\%): $709\left(\mathrm{M}^{+}, 1\right), 695$ (4), 342 (13), 348 (14), 241 (41), 133 (100).

(5o) Mono(5-ethoxy-3-methyl-2-((E)-(4- ((E)-(4-((E)((4-)(E)-(3--methyl-benzo[d]thiazol-3-ium-2-yl) diazenyl)phenyl)imino)methyl)benzylidene)amino) phenyl)diazenyl)benzo[d]thiazol-3-ium mono(methyl sulfate)

Blue powder, yield (82\%), m.p. 272-274 C. IR (KBr) $\left(\mathrm{V}_{\max }, \mathrm{Cm}^{-1}\right): 2978(\mathrm{CH}=), 1623(\mathrm{C}=\mathrm{N}), 1518(\mathrm{C}=\mathrm{C})$, 1289 (C-N); ${ }^{1} \mathrm{H}-\mathrm{NMR}\left(500 \mathrm{MHz}, \mathrm{DMSO}-\mathrm{d}_{6}\right): \delta_{\mathrm{H}} 1.48(\mathrm{t}$, $\left.3 \mathrm{H},{ }^{3} \mathrm{~J}_{\mathrm{HH}} 6.84 \mathrm{~Hz}, \mathrm{CH}_{3}\right), 4.10\left(\mathrm{q}, 2 \mathrm{H},{ }^{3} \mathrm{~J}_{\mathrm{HH}} 6.84 \mathrm{~Hz}\right.$, $\left.\mathrm{OCH}_{2}\right), 4.14\left(\mathrm{~s}, 6 \mathrm{H}, 2 \mathrm{NCH}_{3}\right), 6.99(\mathrm{~s}, 4 \mathrm{H}, 4 \mathrm{CH}), 7.29-$ $8.31(\mathrm{~m}, 15 \mathrm{H}, \mathrm{Ar}), 8.55(\mathrm{~s}, 2 \mathrm{H}, 2 \mathrm{CH})$. MS m/z (\%): 679 $\left(\mathrm{M}^{+}, 3\right), 665$ (6), 342 (16), 318 (6), 241 (34), 133 (100).

(5p) Mono(5-nitro-3-methyl-2-((E)-(4-)((E)-(4-((E)-((4((E)-(3--methyl-benzo[d]thiazol-3-ium-2-yl)diazenyl) phenyl)imino)methyl)benzylidene)amino)phenyl)dia zenyl)benzo[d]thiazol-3-ium mono(methyl sulfate)

Indigo Blue powder, yield (78\%), m.p. 245-247 ${ }^{\circ} \mathrm{C}$. IR $(\mathrm{KBr})\left(\mathrm{V}_{\max }, \mathrm{Cm}^{-1}\right): 2948(\mathrm{CH}=), 1626(\mathrm{C}=\mathrm{N}), 1516$ $(\mathrm{C}=\mathrm{C}), 1294(\mathrm{C}-\mathrm{N}) ;{ }^{1} \mathrm{H}-\mathrm{NMR}\left(500 \mathrm{MHz}, \mathrm{DMSO}-\mathrm{d}_{6}\right): \delta_{\mathrm{H}}$ $4.13\left(\mathrm{~s}, 6 \mathrm{H}, 2 \mathrm{NCH}_{3}, 7.14(\mathrm{~s}, 4 \mathrm{H}, 4 \mathrm{CH}), 7.49\left(\mathrm{~d},{ }^{3} \mathrm{JHH}_{\mathrm{HH}}\right.\right.$ $7.54 \mathrm{~Hz}, 2 \mathrm{CH}), 7.62\left(\mathrm{~d}, 2 \mathrm{H},{ }^{3} J_{\mathrm{HH}} 7.54 \mathrm{~Hz}, 2 \mathrm{CH}\right), 7.75$ (d, $\left.2 \mathrm{H},{ }^{3} \mathrm{~J}_{\mathrm{HH}} 7.54 \mathrm{~Hz}, 2 \mathrm{CH}\right), 7.79\left(\mathrm{~d}, 2 \mathrm{H},{ }^{3} \mathrm{~J}_{\mathrm{HH}} 7.54 \mathrm{~Hz}\right.$, $2 \mathrm{CH}), 7.86\left(\mathrm{t}, 1 \mathrm{H},{ }^{3} \mathrm{~J}_{\mathrm{HH}} 8.28 \mathrm{~Hz}, \mathrm{CH}\right), 7.95\left(\mathrm{t}, 1 \mathrm{H},{ }^{3} \mathrm{~J}_{\mathrm{HH}}\right.$ $8.28 \mathrm{~Hz}, \mathrm{CH}), 8.02\left(\mathrm{~d}, 1 \mathrm{H},{ }^{3} \mathrm{~J}_{\mathrm{HH}} 8.28 \mathrm{~Hz}, \mathrm{CH}\right), 8.10(\mathrm{~d}$, $\left.1 \mathrm{H},{ }^{3} \mathrm{~J}_{\mathrm{HH}} 8.28 \mathrm{~Hz}, \mathrm{CH}\right), 8.32\left(\mathrm{~d}, 1 \mathrm{H},{ }^{3} \mathrm{~J}_{\mathrm{HH}} 8.28 \mathrm{~Hz}, \mathrm{CH}\right)$, $8.42\left(\mathrm{~d}, 1 \mathrm{H},{ }^{3} \mathrm{~J}_{\mathrm{HH}} 8.28 \mathrm{~Hz}, \mathrm{CH}\right), 8.49(\mathrm{~s}, 1 \mathrm{H}, \mathrm{CH}), 8.63$ (s, $2 \mathrm{H}, 2 \mathrm{CH})$. MS m/z (\%): $680\left(\mathrm{M}^{+}, 2\right), 666$ (4), 343 (16), 318 (14), 241 (22), 133 (100).

\section{ACKNOWLEDGEMENTS}

Authors are grateful to the Center of Excellence for Color Science and Technology of Iran for the financial support of this research.

\section{REFERENCES}

[1] Zhang M, Lu W-T, Ruan W, Zhang H-J, Wen T-B. Coppercatalyzed solvent-free redox condensation of benzothiazoles with aldehydes or benzylic alcohols. Tetrahedron Lett 2014; 55: $1806-9$

http://dx.doi.org/10.1016/j.tetlet.2014.01.120

[2] Tong $Y$, Pan Q, Jiang Z, Miao D, Shi X, Han S. A simple approach to benzothiazoles from 2-chloronitrobenzene, elemental sulfur, and aliphatic amine under solvent-free and catalyst-free conditions. Tetrahedron Lett 2014; 55: 5499503.

http://dx.doi.org/10.1016/j.tetlet.2014.08.037
[3]

Prajapati NP, Vekariya RH, Borad MA, Patel HD. Recent advances in the synthesis of 2-substituted benzothiazoles: a review. Rsc Advances 2014; 4: 60176-208. http://dx.doi.org/10.1039/C4RA07437H

[4] Pan L, Yu L, Wu Z, Li Z, Xiang H, Zhou X. Quaternary ammonium salt as alkylation agent in three-component reactions for the synthesis of benzothiazoles in water. Rsc Advances 2014; 4: 27775-9. http://dx.doi.org/10.1039/c4ra04145c

[5] Naeimi H, Tarazian R. Efficient and Facile Catalyst-free OnePot Synthesis and Characterization of Some Novel Bis(2benzothiazole) Derivatives. J Heterocycl Chem 2014; 51: 566-71.

http://dx.doi.org/10.1002/ihet.1956

[6] Kheder NA, Mabkhot YN, Zahian FR, Mohamed SS. Regioselective Synthesis of Some Pyrazole Scaffolds Attached to Benzothiazole and Benzimidazole Moieties. J CHEMISTRY 2014.

[7] Mohamed KS, Abdulaziz NM, Fadda AA. Synthesis of Some New Pyridine and Pyrimidine Derivatives Containing Benzothiazole Moiety. J Heterocycl Chem 2013; 50: 645-9. http://dx.doi.org/10.1002/jhet.1672

[8] Shindy HA, El-Maghraby MA, Eissa FM. Synthesis and colour spectrophotometric measurements of some novel merocyanine dyes. Dyes Pigm 2012; 92: 929-35. http://dx.doi.org/10.1016/j.dyepig.2011.03.019

[9] Shi Q-Q, Sun R, Ge J-F, Xu Q-F, Li N-J, Lu J-M. A comparative study of symmetrical and unsymmetrical trimethine cyanine dyes bearing benzoxazolyl and benzothiazolyl groups. Dyes Pigm 2012; 93: 1506-11. http://dx.doi.org/10.1016/i.dyepig.2011.11.001

[10] Deligeorgiev T, Kaloyanova S, Vasilev A. A novel genera method for preparation of neutral monomethine cyanine dyes. Dyes Pigm 2011; 90: 170-6. http://dx.doi.org/10.1016/i.dyepig.2010.10.012

[11] Zajac M, Hrobarik $P$, Magdolen $P$, Foltinova $P$, Zahradnik $P$ Donor-pi-acceptor benzothiazole-derived dyes with an extended heteroaryl-containing conjugated system: synthesis, DFT study and antimicrobial activity. Tetrahedron 2008; 64: 10605-18.

http://dx.doi.org/10.1016/j.tet.2008.08.064

[12] Avagyan R, Luongo G, Thorsen G, Ostman C. Benzothiazole, benzotriazole, and their derivates in clothing textiles-a potential source of environmental pollutants and human exposure. Environ Sci Pollut Res Int 2014.

[13] Kharbanda C, Alam MS, Hamid H, Javed K, Bano S, Dhulap $\mathrm{A}$, et al. Synthesis and evaluation of pyrazolines bearing benzothiazole as anti-inflammatory agents. Biorg Med Chem 2014; 22 : 5804-12

http://dx.doi.org/10.1016/j.bmc.2014.09.028

[14] Yang Y, Li B, Zhang LM. Design and synthesis of triphenylamine-malonitrile derivatives as solvatochromic fluorescent dyes. Sensors Actuators B: Chem 2013; 183: 4651.

\section{http://dx.doi.org/10.1016/..snb.2013.03.108}

[15] Rufchahi EOM, Yousefi H, Mohammadinia M. Synthesis and spectral properties of some azo disperse dyes containing a benzothiazole moiety. J Mol Liq 2013; 188: 173-7. http://dx.doi.org/10.1016/j.molliq.2013.08.021

[16] Popova A, Christov M, Vasilev A, Zwetanova A. Mono- and dicationic benzothiazolic quaternary ammonium bromides as mild steel corrosion inhibitors. Part I: Gravimetric and voltammetric results. Corros Sci 2011; 53: 679-86. http://dx.doi.org/10.1016/j.corsci.2010.10.005

[17] Popova A, Christov M, Vasilev A. Mono- and dicationic benzothiazolic quaternary ammonium bromides as mild steel corrosion inhibitors. Part II: Electrochemical impedance and polarisation resistance results. Corros Sci 2011; 53: 1770-7. http://dx.doi.org/10.1016/j.corsci.2011.01.055 
[18] Naik S, Alves CMA, Coutinho PJG, Goncalves MST. N(Di)icosyl-Substituted Benzo a phenoxazinium Chlorides: Synthesis and Evaluation as Near-Infrared Membrane Probes. European J Org Chem 2011: 2491-7. http://dx.doi.org/10.1002/ejoc.201001579

[19] Fujii K, Kuroda T, Sakoda K, lyi N. Fluorescence resonance energy transfer and arrangements of fluorophores in integrated coumarin/cyanine systems within solid-state twodimensional nanospace. J Photochem Photobiol A 2011; 225: 125-34.

http://dx.doi.org/10.1016/j.jphotochem.2011.10.009

[20] Pandey AK, Deakin PC, Jansen-Van Vuuren RD, Burn PL, Samuel IDW. Photo-Rechargeable Battery Effect in First Generation Cationic-Cyanine Dendrimers. Adv Mater 2010; 22: 3954-+.

http://dx.doi.org/10.1002/adma.200904464

[21] Jedrzejewska B, Pietrzak M, Paczkowski J. Tetramethylammonium phenyltrialkylborates as co-initiators with novel two-cationic styrylbenzimidazolium dyes in highly efficient, visible light polymerization of acrylate. J Photochem Photobiol A 2010; 214: 276-83. http://dx.doi.org/10.1016/j.jphotochem.2010.07.012

[22] Kim JY, Kim TH, Kim DY, Park N-G, Ahn K-D. Novel thixotropic gel electrolytes based on dicationic bisimidazolium salts for quasi-solid-state dye-sensitized solar cells. J Power Sources 2008; 175: 692-7.

http://dx.doi.org/10.1016/j.jpowsour.2007.08.085

[23] Suzuki T, Iwai T, Ohta E, Kawai H, Fujiwara K. Electrochiroptical systems based on biphenyl-2,2 '-diyl-type dicationic dyes: strong chiroptical signals through the transmission of point chirality to axial chirality. Tetrahedron Lett 2007; 48: 3599-603. http://dx.doi.org/10.1016/j.tetlet.2007.03.080

[24] Suzuki T, Iwashita S, Yoshino T, Kawai H, Fujiwara K, Ohkita $\mathrm{M}$, et al. The first stable tetraarylacenaphthenequinodimethanes exhibiting electrochromism with 'writeprotect' option: preparation, highly deformed structure, and reversible interconversion with acenaphthylene-5,6-diyl dicationic dyes. Tetrahedron Lett 2006; 47: 467-71. http://dx.doi.org/10.1016/.tetlet.2005.11.059

[25] Yin G-L, Li Y, Tang K, Jin X-F, Chen X-G, Li L, et al. Synthesis and biological evaluation of 2-(3butynoicamidophenyl) benzothiazole derivatives as antitumor agents. Yao xue xue bao = Acta pharmaceutica Sinica 2014; 49: 888-95

[26] Wang S, Chen Y, Zhao S, Xu X, Liu X, Liu B-F, et al. Synthesis and biological evaluation of a series of benzoxazole/benzothiazole-containing 2,3-dihydrobenzo b 1,4 dioxine derivatives as potential antidepressants. Bioorg Med Chem Lett 2014; 24: 1766-70. http://dx.doi.org/10.1016/j.bmcl.2014.02.031

[27] Singh M, Singh SK. Benzothiazoles: How Relevant in Cancer Drug Design Strategy? Anticancer Agents Med Chem 2014; 14: $127-46$

http://dx.doi.org/10.2174/18715206113139990312

[28] Singh M, Gangwar M, Nath G, Singh SK. Synthesis, DNA cleavage and antimicrobial activity of 4-thiazolidinonesbenzothiazole conjugates. Indian J Exp Biol 2014; 52: 106270.

[29] Riswan Ahamed MA, Azarudeen RS, Kani NM. Antimicrobial applications of transition metal complexes of benzothiazole based terpolymer: synthesis, characterization, and effect on bacterial and fungal strains. Bioinorg Chem Appl 2014; 2014: 764085-.

http://dx.doi.org/10.1155/2014/764085

[30] Ma J, Zhang G, Han X, Bao G, Wang L, Zhai X, et al. Synthesis and Biological Evaluation of Benzothiazole Derivatives Bearing the ortho-Hydroxy-N-acylhydrazone
Moiety as Potent Antitumor Agents. Arch Pharm 2014; 347: 936-49.

http://dx.doi.org/10.1002/ardp.201400230

[31] Li H, Wang X-M, Wang J, Shao T, Li Y-P, Mei Q-B, et al. Combination of 2-methoxy-3-phenylsulfonylaminobenzamide and 2-aminobenzothiazole to discover novel anticancer agents. Biorg Med Chem 2014; 22: 3739-48.

http://dx.doi.org/10.1016/j.bmc.2014.04.064

[32] Kumbhare RM, Dadmal TL, Pamanji R, Kosurkar UB Velatooru LR, Appalanaidu K, et al. Synthesis of novel fluoro 1,2,3-triazole tagged amino bis(benzothiazole) derivatives, their antimicrobial and anticancer activity. Med Chem Res 2014; 23: 4404-13.

http://dx.doi.org/10.1007/s00044-014-1006-0

[33] Wang C, Xu F, Niu Y, Wu Y, Sun J, Peng Y, et al. Synthesis and Biological Evaluations of 3-Benzothiazol-2-yl Coumarin Derivatives as MEK1 Inhibitors. Lett Drug Des Discov 2013; 10: 727-32.

http://dx.doi.org/10.2174/15701808113109990012

[34] Patel AB, Sahoo SK, Chikhalia KH, Kumari P. Design, Synthesis and Computational Studies of New Benzothiazole Substituted Quinazolines as Potential Antimicrobial Agents. Lett Drug Des Discov 2013; 10: 957-66.

\section{http://dx.doi.org/10.2174/15701808113109990025}

[35] Kamal A, Faazil S, Ramaiah MJ, Ashraf M, Balakrishna M, Pushpavalli SNCVL, et al. Synthesis and study of benzothiazole conjugates in the control of cell proliferation by modulating Ras/MEK/ERK-dependent pathway in MCF-7 cells. Bioorg Med Chem Lett 2013; 23: 5733-9. http://dx.doi.org/10.1016/j.bmcl.2013.07.068

[36] Liu ZR, Rill RL. N,N'-bis 3,3'-(dimethylamino)propylamine 3,4,9,10-perylenetetracarboxyl ic diimide, a dicationic perylene dye for rapid precipitation and quantitation of trace amounts of DNA. Anal Biochem 1996; 236: 139-45. http://dx.doi.org/10.1006/abio.1996.0142

[37] Nourmohammadian F, Gholami MD. Synthesis and Characterization of Some Novel Dichromophoric Cyanine Dyes. Synth Commun 2009; 39: 1981-91. http://dx.doi.org/10.1080/00397910802630195

[38] Nourmohammadian F, Gholami MD. Two Novel Push-Pull Series of Benzothiazole-Based Dyes: Synthesis and Characterization. Helv Chim Acta 2012; 95: 1548-55. http://dx.doi.org/10.1002/hlca.201200080

[39] Nourmohammadian F, Gholami MD. Synthesis of Fluorescent Dichromophoric Benzothiazole-Based Polyenes. Lett Org Chem 2012; 9: 720-31. http://dx.doi.org/10.2174/157017812803901863

[40] Reichardt C. Solvatochromic dyes as empirical indicators of solvent polarity. Chimia 1991; 45: 322-4.

[41] Reichardt C. Solvatochromic dyes as solvent polarity indicators. Chem Rev 1994; 94: 2319-58. http://dx.doi.org/10.1021/cr00032a005

[42] Suman GR, Bubbly SG, Gudennavar SB, Thipperudrappa J, Roopashree B, Gayathri V, et al. Effect of solvents on photophysical properties and quenching of $2-\{[3-(1 \mathrm{H}-$ benzimidazole-2-yl) phenyl] carbonoimidoyl\}phenol. Luminescence 2014. http://dx.doi.org/10.1002/bio.2794

[43] Pannipara M, Asiri AM, Alamry KA, Arshad MN, El-Daly SA. Spectroscopic investigation, effect of solvent polarity and fluorescence quenching of a new D-pi-A type chalcone derivative. J Fluoresc 2014; 24: 1629-38. http://dx.doi.org/10.1007/s10895-014-1449-1

[44] Ceron-Carrasco JP, Jacquemin D, Laurence C, Planchat A, Reichardt C, Sraidi K. Solvent polarity scales: determination of new E-T(30) values for 84 organic solvents. J Phys Org Chem 2014; 27 : 512-8. http://dx.doi.org/10.1002/poc.3293 
[45] Martinez-Martinez V, Lim J, Banuelos J, Lopez-Arbeloa I, Miljanic OS. Strong intramolecular charge transfer emission in benzobisoxazole cruciforms: solvatochromic dyes as polarity indicators. PCCP 2013; 15: 18023-9.

http://dx.doi.org/10.1039/c3cp53527d
[46] Gilani SJ, Khan SA. Synthesis and pharmacological evaluation of $\mathrm{N}$-(6-chlorobenzo d thiazol-2-yl)hydrazine carboxamide derivatives of benzothiazole. Med Chem Res 2013; 22: 3316-28.

http://dx.doi.org/10.1007/s00044-012-0329-y 